\title{
Driving Chromatin Organisation through N6-methyladenosine Modification of RNA: What Do We Know and What Lies Ahead?
}

\author{
Tommaso Selmi ${ }^{1, *(\mathbb{D})}$ and Chiara Lanzuolo ${ }^{1,2}$ (D) \\ 1 Consiglio Nazionale delle Ricerche, Istituto di Tecnologie Biomediche, Via Fratelli Cervi 93, \\ 20054 Milano, Italy; chiara.lanzuolo@cnr.it \\ 2 Istituto Nazionale di Genetica Molecolare, Via Francesco Sforza 35, 20122 Milano, Italy \\ * Correspondence: tommaso.selmi@itb.cnr.it
}

Citation: Selmi, T.; Lanzuolo, C. Driving Chromatin Organisation through N6-methyladenosine Modification of RNA: What Do We Know and What Lies Ahead? Genes 2022, 13, 340. https://doi.org/ 10.3390 /genes 13020340

Academic Editors: María Gomez and Sandra Blanco Benavente

Received: 30 December 2021

Accepted: 9 February 2022

Published: 12 February 2022

Publisher's Note: MDPI stays neutral with regard to jurisdictional claims in published maps and institutional affiliations.

Copyright: (C) 2022 by the authors. Licensee MDPI, Basel, Switzerland. This article is an open access article distributed under the terms and conditions of the Creative Commons Attribution (CC BY) license (https:// creativecommons.org/licenses/by/ $4.0 /)$.

\begin{abstract}
In recent years, there has been an increase in research efforts surrounding RNA modification thanks to key breakthroughs in NGS-based whole transcriptome mapping methods. More than 100 modifications have been reported in RNAs, and some have been mapped at single-nucleotide resolution in the mammalian transcriptome. This has opened new research avenues in fields such as neurobiology, developmental biology, and oncology, among others. To date, we know that the RNA modification machinery finely tunes many diverse mechanisms involved in RNA processing and translation to regulate gene expression. However, it appears obvious to the research community that we have only just begun the process of understanding the several functions of the dynamic web of RNA modification, or the "epitranscriptome". To expand the data generated so far, recently published studies revealed a dual role for N6-methyladenosine (m6A), the most abundant mRNA modification, in driving both chromatin dynamics and transcriptional output. These studies showed that the m6A-modified, chromatin-associated RNAs could act as molecular docks, recruiting histone modification proteins and thus contributing to the regulation of local chromatin structure. Here, we review these latest exciting findings and outline outstanding research questions whose answers will help to elucidate the biological relevance of the m6A modification of chromatin-associated RNAs in mammalian cells.
\end{abstract}

Keywords: N6-methyladenosine; chromatin; histone modifications; transposable elements; chromatinassociated RNAs; transcription; LLPS (Liquid-Liquid Phase Separation)

\section{RNA Modifications}

More than 100 RNA modifications have been reported in the transcriptome of organisms spanning from archaea to eukaryotes [1]. These chemical alterations of RNA nucleotides expand the properties of a given RNA sequence, thus affecting its function [2]; however, the precise effect of each modification on distinct RNAs and the consequences on genome function are still the subjects of intensive research. In experimental models, RNA modifications appear dynamically regulated, primarily as a form of adaptation to stress. Modifications are present at high frequency in abundant and stable RNA molecules, such rRNAs and tRNAs, and to a lower extent in other RNAs, such as mRNAs, and other non-coding RNAs such as long non-coding RNAs (lncRNAs) and small nuclear RNAs (snRNAs) [3,4]. The depletion of the enzymes belonging to the RNA modification machinery shed partial light on the biological function of a few of these modifications, and genetic studies uncovered a robust association between mutations of RNA modifying enzymes, developmental defects [5], and cancer [6].

\subsection{N6-methyladenosine in Mammals}

N6-methyladenosine (m6A) is the most abundant internal mRNA modification, occurring at a frequency of 1-3 nt/1000 nt, [7,8], mostly in the coding sequence and in the 
$3^{\prime}$ untranslated region ( $\left.3^{\prime} \mathrm{UTR}\right)$, and is significantly enriched around stop codons at the consensus motif RRACH ( $\mathrm{R}=\mathrm{A}$ or $\mathrm{G}, \mathrm{H}=\mathrm{A}, \mathrm{C}, \mathrm{U})$ [9-11]. Data suggest that m6A deposition happens co-transcriptionally in the nucleus $[12,13]$ and is catalysed by the methyltransferase complex (MTC) $[14,15]$, which is composed by a core catalytic heterodimer including METTL3 (methyltransferase-like 3) and METTL14 (methyltransferase-like 14) [14,16], and additional factors (WTAP, ZC3H13, RBM15/RBM15B, VIRMA) with regulatory functions [14,17-20]. METTL3 knockout mice display embryonic lethality, as the METTL3 protein regulates naïve pluripotency genes, and its depletion leads to imperfect termination of the naïve state [21].

In addition to mRNAs, m6A also occurs in non-coding RNAs, such as a group of primary microRNAs (pri-miRNAs), where it has been shown to regulate their processing [22]; in lncRNAs, where it has been shown to regulate functional activities [23,24]; and in the non-coding small nuclear RNA (snRNP) U6 [25,26], potentially affecting pre-mRNA splicing. Data suggest that METTL3 and METTL14 are responsible for most of the poly(A) mRNA m6A deposition, while METTL16 (methyltransferase-like 16) [27] appears to mostly target structured RNAs contained in intronic sequences and non-coding RNAs, [25], although not exclusively $[26,28]$. Similar to what has been observed with METTL3, knockout attempts of METTL6 in mice resulted in embryonic lethality [29].

A group of five m6A reader proteins named the YT521-B homology (YTH) domaincontaining proteins (YTHDC1, YTHDC2, YTHDF1-3) directly bind to m6A methylated RNAs through the highly conserved YTH domain [30,31]. Of the 5 members of this family, YTHDC1 is involved in mediating splicing regulation and trafficking in the nucleus [32,33], while YTHDC2 binds to m6A residues in mRNAs of germ cells, affecting their maturation [34]. Knockout of YTHDC1 is embryonically lethal, and its depletion from mouse male/female germ cells impairs their maturation [35]. On the other hand, YTHDC2 knockout mice are viable but infertile [36]. With regard to YTHDF1-3, these were originally identified with diverse functions affecting mRNA translation or turnover [37,38]; however, recent work suggests that YTHDF1-3 might preferentially regulate mRNA turnover, with some degree of functional redundancy $[39,40]$.

Additional readers, hnRNPG [41], hnRNPC [2], hnRNPA2/B1 [22] (heterogeneous nuclear ribonucleoproteins), and IGF2BP (insulin-like growth factor binding protein) [42], all lacking the m6A-binding YTH domain, appear to mediate m6A-dependent functions, such as transcripts' splicing and turnover. Given the ability of m6A to destabilise RNA hairpins [43,44] to expose RNA binding motifs, these readers might be recruited on m6ARNAs by changes in the methylated RNA's secondary structure [2,43-45].

The two only known m6A demethylases belong to the Fe(II) / $\alpha$-ketoglutarate-dependent dioxygenase family (ALKB) [46]. The discovery of such specialised m6A "erasers" has been fundamental to the definition of the dynamic nature of the m6A "epitranscriptome". The "eraser" enzyme ALKBH5 (ALKB homolog 5) is specifically active on the m6A modification [47] and is up-regulated in some cancers, where it promotes the stabilisation of oncogenes during hypoxia [48]. The other known m6A demethylase is FTO (fat mass and obesity associated gene). Despite having been originally characterised as the main m6A demethylase [49], FTO shows stronger enzymatic activity towards $\mathrm{N}^{6}, 2^{\prime}$-O-dimethyladenosine $\left(\mathrm{m}^{6} \mathrm{Am}\right)$, especially in snRNAs [50]. FTO knockout causes splicing defects [51] and acts as an oncogene in acute myeloid leukaemia [52].

Overall, m6A mainly regulates gene expression by affecting mRNA stability and promoting its turnover $[37,53-55]$, however, published literature also suggest that m6Acarrying mRNAs undergo increased cap-dependent translation [56], and data obtained under stress conditions support a model where the m6A modification of $5^{\prime} \mathrm{UTR}\left(5^{\prime}\right.$ untranslated region) mediates cap-independent translation [57,58]. Finally, m6A could regulate splicing of a group of mRNAs by the interaction of the nuclear m6A reader YTHDC1 with members of the SRF (serine/arginine (SR)-rich proteins) protein family in nuclear speckles [32].

The genetic perturbation of the m6A machinery (writer, reader, and eraser genes) in different experimental models affects a striking variety of molecular processes including, but not 
restricted to: adipogenesis [59], spermatogenesis [15,34], oocyte maturation [35,60], neurodevelopment [61-63], pluripotency [21,54,55], circadian rhythm regulation [64], senescence [65], multiple cancerous traits [52,66-72], and antitumor immunity $[73,74]$.

\section{2. $m 6 \mathrm{~A}$ and Epigenomic Regulation}

The phenotypic pleiotropy [75] that derives from the experimental perturbation of the m6A machinery has been ascribed to the central role that this modification plays in the cell. This could potentially point to the limitations of classic genetic experimental approaches for the study of cellular modification shared by so many targets [75]. In light of the recent reports reviewed here, the variety of phenotypes associated with m6A-preturbations could, at least partly, depend on the direct action of m6A on the epigenome. In support of an epigenetic role of $\mathrm{m} 6 \mathrm{~A}$, previous literature shows that METTL3-dependent m6A regulates $\mathrm{X}$-chromosome inactivation via a group of methylated adenosine residues on theXIST (X-inactive specific transcript) lncRNA that are bound by the nuclear m6A reader YTHDC1 [23]. Furthermore, in multiple human breast cancer cell lines, m6A modification of nucleotide A783 of the developmentally regulated HOTAIR lncRNA (HOX antisense intergenic RNA) determines the loss of the lncRNA's repressive function, promoting proliferation and invasiveness [76]. Lastly, in mouse neural stem cells, the genetic depletion of m6A writers has been found to enhance the degradation of mRNAs encoding for acetyltransferase EP300 (E1A-associated protein p300) and CBP (CREB-binding protein), hence regulating the abundance of activating histone modifications [62]. For the keen reader, the epigenetic effects of m6A have also been summarised recently by Kan and colleagues [77] and Zhao and colleagues [78]. Table 1 outlines examples of the interplay between m6A and chromatin accessibility.

Table 1. The interplay between m6A and chromatin accessibility.

\begin{tabular}{|c|c|c|c|c|c|c|c|}
\hline Cells & Writer/Reader & Target RNA & $\begin{array}{l}\text { Histone } \\
\text { Signature }\end{array}$ & $\begin{array}{c}\text { Effect of Writer } \\
\text { or Reader KOon } \\
\text { Histone } \\
\text { Signature }\end{array}$ & Affected Genomic Loci & Biological Function of m6A & Refs. \\
\hline $\mathrm{mNSc}$ & METTL14 & $\begin{array}{l}\text { CBP, P300 } \\
\text { mRNAs }\end{array}$ & $\begin{array}{l}\text { H3K27ac } \\
\text { H3K27me3 }\end{array}$ & Increased & $\begin{array}{l}\text { Proliferation/differentiation } \\
\text { gene sets }\end{array}$ & $\begin{array}{l}\text { Regulating self-renewal } \\
\text { and differentiation }\end{array}$ & [62] \\
\hline $\mathrm{mESc}$ & $\begin{array}{l}\text { METTL3, } \\
\text { METTL14, } \\
\text { YTHDC1 }\end{array}$ & $\begin{array}{l}\text { carRNAs, } \\
\text { LINE1 }\end{array}$ & $\begin{array}{l}\text { H3K4me3 } \\
\text { H3K27ac }\end{array}$ & Increased & $\begin{array}{c}\text { eRNAs, } \\
\text { paRNAs, } \\
\text { repeat RNAs }\end{array}$ & $\begin{array}{l}\text { Repressing transcription at } \\
\text { intergenic regions }\end{array}$ & [79] \\
\hline $\mathrm{mESc}$ & $\begin{array}{l}\text { YTHDC1, } \\
\text { METTL3 }\end{array}$ & $\begin{array}{l}\text { IAPs, } \\
\text { LINE1 }\end{array}$ & H3K9me3 & Decreased & $\begin{array}{l}\text { IAP repeats, } \\
\text { Dux1 locus }\end{array}$ & $\begin{array}{l}\text { Repressing transcription of 2C-like } \\
\text { state genes }\end{array}$ & {$[80,81]$} \\
\hline mESc & $\begin{array}{l}\text { METTL3, } \\
\text { YTHDC1 }\end{array}$ & IAPs & $\begin{array}{l}\text { H3K9me3 } \\
\text { H3K20me3 }\end{array}$ & Decreased & IAP repeats & $\begin{array}{l}\text { Maintaining heterochromatin at } \\
\text { repeat elements }\end{array}$ & [82] \\
\hline $\mathrm{mESc}$ & $\begin{array}{l}\text { METTL3, } \\
\text { METTL14, } \\
\text { YTHDF2 }\end{array}$ & IAPs & H3K9me3 & $\begin{array}{l}\text { No significant } \\
\text { change }\end{array}$ & ERVs & Repressing transcription of ERVs & [83] \\
\hline mESC & $\begin{array}{l}\text { METTL3, } \\
\text { METTL4 }\end{array}$ & $\begin{array}{l}\text { MSR } \\
\text { LINE1 }\end{array}$ & H3K9me3 & $\begin{array}{l}\text { No significant } \\
\text { change }\end{array}$ & $\begin{array}{l}\text { MSR } \\
\text { LINE1 }\end{array}$ & $\begin{array}{l}\text { Promoting the formation of } \\
\text { RNA:DNA hybrids }\end{array}$ & [84] \\
\hline $\begin{array}{l}\text { HEK293, } \\
\text { mESc }\end{array}$ & $\begin{array}{l}\text { METTL3, } \\
\text { YTHDC1 }\end{array}$ & mRNAs & H3K9me2 & Decreased & Gene bodies & $\begin{array}{l}\text { Promoting co-transcriptional } \\
\text { histone de-methylation and } \\
\text { transcriptional output }\end{array}$ & [85] \\
\hline $\mathrm{mESc}$ & METTL14 & $\begin{array}{l}\text { MYC } \\
\text { ACTB }\end{array}$ & H3K36me3 & $\begin{array}{l}\text { No significant } \\
\text { change }\end{array}$ & Gene rich regions & Methylate nascent RNAs & [86] \\
\hline THP1 & YTHDF2 & $\begin{array}{l}\text { KDM6B } \\
\text { mRNA }\end{array}$ & H3K27me3 & Decreased & $\begin{array}{l}\text { IL-6, IL-12B, CCL22, } \\
\text { ICAM1 }\end{array}$ & $\begin{array}{l}\text { Restraining the expression of } \\
\text { pro-inflammatory cytokines }\end{array}$ & [87] \\
\hline
\end{tabular}

eRNAs: enhancer RNAs; paRNAs: promoter-associated RNAs; IAP: intracisternal A particle; LINE1: long interspersed nuclear elements; MSR: major satellite repeats; ERVs: endogenous retroviruses.

\section{Transposable Elements, RNA Modifications, and Chromatin Organisation}

The human and murine genomes are characterised by the presence of highly repetitive elements (RE), contributing to an estimated $50 \%$ and $70 \%$ of their genetic material, respectively [88]. Transposable elements (TE) are a class of RE that integrate in the host genome through either RNA or DNA intermediates. Among the RNA retrotransposons, 
LTR derive from ancient retroviruses, thus they encode for viral ORFs and carry $5^{\prime}$ and $3^{\prime}$ long terminal repeats (LTR). Even though they are mostly inactive, the youngest evolutionary LTR families, such as ERV-I, ERV-II, and ERV-K (endogenous retroviruses) in humans, and intracisternal A particle (IAP) elements in mice, are capable of retrotransposition [88]. Moreover, non-LTR retrotransposons are also capable of autonomous integration and are referred to as long interspersed nuclear elements (LINEs) [89]. To prevent random integration and interference with gene transcription networks, TEs are subject to constant silencing, achieved by epigenetic mechanisms such as histone H3K9me3 and DNA methylation, and RNA interference by small RNAs, such as piRNAs (Piwi interacting RNAs). TEs are thought to play a key role in the evolution of the genome, and TE distribution into the genome is not random; in fact, they are arranged in domains of heterochromatin [90,91]. Interestingly, similar to what happens to RNA modifications, the activation of TEs in the eukaryotic genome can be triggered by stress conditions [92].

Evidence that RNA modifications can control TE expression comes from earlier studies in the Drosophila model, where DNMT2, a tRNA 5-cytosine methyltransferase (m5C), appears to contribute to the inhibition of TE re-activation [93]. Such findings have recently been confirmed and more thoroughly investigated by Genenncher and colleagues, who demonstrated that $\mathrm{KO}$ of both the tRNA m5C transferases NSUN2 and DNMT2 promotes TE re-activation and genomic instability [94]. The authors hypothesise that NSUN2 and DNMT2 achieve TE silencing by promoting the translation of chromatin remodelling complexes, rather than by direct modification of the TE. Even though more work is needed to draw robust conclusions on the molecular mechanisms involved, these studies point toward an active interplay between the RNA modification machinery and the maintenance of genomic stability via the regulation of TE.

\subsection{IAP and LINE Regulation by $m 6 A$ and Histone Modifications in Mouse Embryonic Stem Cells}

Transcriptional re-activation of certain families of TEs takes place during the epigenetic reprogramming of mESc $[95,96]$. Although originally thought to be a consequence of increased chromatin accessibility during embryonic reprogramming, the re-activation of LINE-1 elements is now considered as an integral part of this process [96]. In fact, timely LINE1 activation ensures the correct resolution of early transcriptional programs. Moreover, different studies have shown that TEs, including IAPs, are kept inactive by mechanisms that are alternative to DNA methylation [97-99].

Three studies have recently reported the regulatory activity of m6A over LINE1 in mouse ES cells [79-81]. The first study [79], which looked at genome-wide regulation of chromatin accessibility by m6A (Figure 1A), found the robust enrichment of m6A at chromatin-associated repetitive RNAs (carRNAs) of the mESc genome. The LINE1 family of carRNAs showed the most significant reduction in m6A after METTL3 KO, coupled with increased stability. This correlated with genome-wide enhanced chromatin accessibility and the deposition of active histone marks such as H3K4me3 and H3K27ac, possibly mediated by the action of EP300 (histone acetyltransferase p300) and YY1 (Yin Yang 1 transcription factor). Biologically, the modulation of the methylation levels of LINE1 in METTL3 KO mESc affected self-renewal and differentiation potentials [79]. 

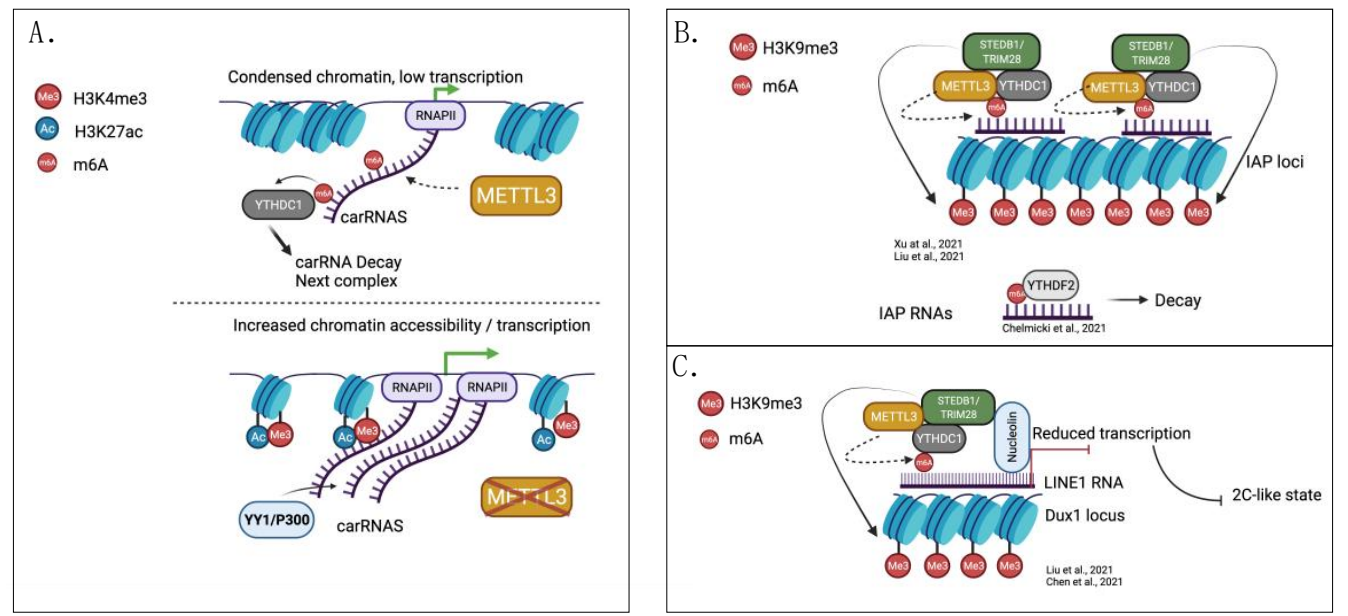

Figure 1. The regulation of transposable elements and chromatin accessibility by m6A. (A) METTL3dependent methylation of carRNAs maintains condensed chromatin at intergenic regions and promotes carRNAs degradation by the NEXT (nuclear exosome targeting) complex. Loss of carRNA methylation leads to increased chromatin accessibility and enriched transcription, associated with increased histone H3-lysine4 trimethylation (H3K4me3) and histone H3-lysine27 acetylation (H3K27ac). carRNAs can now recruit epigenetic factors such as YY1 and EP300 to maintain an open chromatin conformation and downstream transcription. (B) METTL3 deposits m6A on intracisternal A particle (IAP) RNAs. YTHDC1 recognises and binds to methylated IAPs, and in conjunction with METTL3 recruits the histone methyltrasferase SETDB1 and its co-factor TRIM28. This complex establishes histone H3-lysine9 trimethylation and maintains a closed chromatin conformation at IAP loci. This leads to an overall reduction in the transcription of IAP RNAs. m6A-marked IAP RNAs are degraded by YTHDF2. (C) m6A-marked LINE1 silences the Dux1 locus in mouse embryonic stem cells to prevent the activation of the $2 \mathrm{C}$-like state transcriptional program. Methylated LINE1 recruits the methyltransferse SETDB1 and its co-factor TRIM28 through YTHDC1. Nucleolin also takes part in the silencing complex assembled over the m6A-marked LINE1. Created with BioRender.com.

In a complementary study [80], Liu and colleagues focused on the role of the nuclear m6A reader YTHDC1 in silencing TEs (LINE1, ERVK, IAPs) (Figure 1B). The authors found that YTHDC1 acted by reducing the levels of m6A-marked TE RNAs through direct binding. The RNA-bound YTHDC1 recruited the histone methyltransferase SETDB1 (SET domain bifurcated histone lysine methyltransferase 1) to promote the deposition of H3K9me3 at the corresponding loci, in order to repress chromatin accessibility. Biologically, the m6A binding activity of YTHDC1 was key in preventing the activation of a stem cell-specific 2C-like transcriptional state [80]. In the absence of YTHDC1, m6A-marked LINE1 was recruited on the Dux1 locus where it mediated chromatin repression [80]. These findings were confirmed in a follow up study by Chen et al., who found that m6A-marked LINE1 can complex with Nucleolin (NCL) to inhibit the re-expression of TE, controlling the execution of the 2C-like state program [81] (Figure 1C).

The m6A machinery appears to be necessary to maintain heterochromatin marks at the intracisternal A particle (IAP)-type family too, as reported by two studies [82,83]. In their work, $\mathrm{Xu}$ and colleagues [82] observed the METTL3-dependent deposition of repressive H3K9me3 and H4K20me3 at IAP elements, and m6A-dependent IAP RNA de-stabilisation. According to their model, METTL3 mediated the methylation of IAP RNAs and recruited YTHDC1. Importantly, for their repressive function, m6A-marked IAP RNAs were retained at their chromosomal loci. The METTL3-YTHDC1 subsequently recruited SETBD1 and TRIM28 (tripartite motif containing 28) to repress chromatin accessibility via histone methylation (Figure 1B). Concomitantly, Chelmicki and colleagues [83] published very similar findings while performing a whole-genome CRISPR screen for the identification of novel negative regulators of ERV activation. Using $\mathrm{KO}$ cells and auxin-inducible degron constructs (AID, which allow for an acute and reversible depletion of the METTL3 protein), the 
authors confirmed the presence of m6A in IAP RNAs; moreover, they found that the reader YTHDF2 binds to methylated IAPs to promote their turnover (Figure 1B). Accordingly, the authors found increased levels of IAPs in m6A-depleted cells, however, they noted that other TEs like LINEs, which also carry METTL3-/METTL14-dependent m6A, appeared to be stabilised by $\mathrm{m} 6 \mathrm{~A}$, and might therefore be regulated by other $\mathrm{m} 6 \mathrm{~A}$ readers. Importantly, the authors focused on the acute effects of m6A depletion and showed that IAPs were quickly degraded in response to the deposition of m6A, although not concomitantly with the formation of heterochromatin at the corresponding genomic loci. This study employed AID, an important experimental alternative to genetic $\mathrm{KO}$, whose results suggest that histone modifications observed in genetic $\mathrm{KO}$ models could arise from the process of cellular adaptation to the long-term depletion of $\mathrm{m} 6 \mathrm{~A}$, but might not be readily installed upon loss of the modification to the IAP RNAs [83].

\subsection{MSR Repeats Turnover and RNA:DNA Hybrid Formation by $m 6 A$}

Major satellite repeats (MSR) are repeated DNA elements of constitutive heterochromatin spanning the peri-centromeric areas of the chromosome [100]. A portion of these sequences are transcriptionally active, and when transcribed they form RNA:DNA hybrids (R loops) that recruit HP1 (heterochromatin protein 1) and the SUV39 (suppressor of variegation 3-9) histone methyltransferase to maintain the local H3K9me3 and compact chromatin structure, ultimately ensuring the maintenance of genome integrity [101,102]. $R$ loops are RNA:DNA hybrids that form between the nascent mRNA and the DNA, mainly during transcription and in response to DNA damage. The role of $\mathrm{R}$ loops in controlling gene expression and genomic integrity has been demonstrated in a number of mammalian models [103], and in some instances, m6A of RNAs in R loops exerts control over their formation and resolution. For example, in cancer cell lines, METTL3-dependent m6A promotes the formation and stability of $\mathrm{R}$ loops at genomic sites of double-strand breaks through the binding of YTHDC1 [104]. On the other hand, in pluripotent stem cells, the binding of YTHDF2 to R loops that are m6A-marked triggers their degradation [105]. So far, data support the existence of a connection between m6A and R loops, however, the details of the regulatory effects of $\mathrm{m} 6 \mathrm{~A}$ over these structures (and vice versa) are not clear, as these might depend on the cell context and/or on the specific R loop trigger event.

In their study, Duda and colleagues investigated the potential involvement of $\mathrm{m} 6 \mathrm{~A}$ in the process of MSR silencing [84]. They showed that MSR were targeted by METTL3/METTL14 in vitro, and that m6A modification of MSR decreased in METTL3 and METTL14 KO mES cells. M6A of MSR RNAs promoted their association to chromatin and the generation of RNA:DNA hybrids. The study also provided a quantification of the methylated fraction of MSR repeats and LINE1 (20\% and $70 \%$ of transcripts, respectively), and reported the stabilising effect of m6A on these two families. However, the methylation of MSR and LINE1 did not entirely depend on METTL3/METTL14, as KO cells showed residual methylation of these RNAs. The authors did not investigate the mechanism of MSR and LINE1 stabilisation in their mouse ES cells models in detail, although they suggest that neither YTHDC1 nor YTHDC2 showed increased in vitro affinity for m6A-MSR, hinting to the presence of other unidentified factors that can bind these two classes of m6A modified RNAs [84].

Another interesting observation from this study is the quantification of both $\mathrm{m} 5 \mathrm{C}$ and m6A on the bulk of chromatin-associated RNAs by two methods (LC-Mass spectrometry and $\mathrm{m} 5 \mathrm{C} / \mathrm{m} 6 \mathrm{~A}$ meRIP). This showed that $\mathrm{m} 5 \mathrm{C}$ is only present at low intensities in this fraction, as opposed to significantly higher m6A levels [84]. Due to its nearly background level, the authors have excluded a regulatory role for $\mathrm{m} 5 \mathrm{C}$. This is an interesting observation, as earlier studies reported that $\mathrm{m} 5 \mathrm{C}$ might regulate local chromatin organisation by the methylation of nascent mRNAs [106] and enhancer RNAs (eRNAs) [107]. It is well described that epigenetic mechanisms are genomic-site-dependent; therefore, based on this data, it cannot be excluded that $\mathrm{m} 5 \mathrm{C}$ or other modifications might have regulatory roles on subsets of specific RNAs at different chromatin loci, or perhaps even cooperate with m6A. 
With regards to this possibility, the interplay between $\mathrm{m} 6 \mathrm{~A}$ and $\mathrm{m} 5 \mathrm{C}$ has been reported to enhance the translation of the mRNA of p21 in the cytoplasm [108].

Lastly, the authors observed no significant alteration to H3K9me3 levels or HP1 localisation in METTL3 and METTL14 KO cells [84], as opposed to what has been reported by the other studies that focused specifically on LINE and IAP elements after the genetic knockout of MTC components or of the reader YTHDC1 [79-82].

\subsection{Summary of: Transposable Elements, RNA Modifications, and Chromatin Organisation}

The reviewed data provides robust evidence that m6A ensures the correct execution of the differentiation programme of $\mathrm{mESc}$ by preventing the uncontrolled re-activation of transposable elements (IAPs, LINE1). This relies on the nuclear crosstalk between m6A of TE-RNAs and repressive epigenetic factors. Within this circuit, two levels of TE-RNA repression could co-exist: (1) the m6A-dependent recruitment of TRIM28 and SETDB1, exerted by METTL3 and YTHDC1, which is critical to the establishment of a H3K9me3 repressive environment [80-82], and (2) the degradation of m6A-marked TE transcripts involving the readers YTHDC1 and YTHDF2 [79,83]. In experimental settings however, some classes of TEs bound by YTHDC1 were destabilised by m6A modification (IAPs) while others were stabilised or showed opposite trends in similar studies, suggesting that an additional m6dependent regulation of TEs takes place. This could be dependent on the activity of additional m6A methyltransferases (METTL5, METTL16, and ZCCHC4) $[26,109,110]$ as suggested by Duda and colleagues [84], or depend on the activity of reader proteins, which could be tuned by post-translational modifications or other molecular interactions.

\section{Chromatin Accessibility, Transcriptional Regulation, and m6A}

The link between m6A and accessible, transcribed chromatin has been established by different studies. In particular, according to Slobodin and colleagues, the deposition of m6A happens co-transcriptionally and the processivity rate of RNA polymerase II affects the overall level of transcript m6A methylation and its translation [12]. The METTL3 association with chromatin is a process that is also regulated by heat shock, leading to the methylation of specific transcripts during hypothermia [13]. In human leukaemia cells, the CEBPz (CAATT-enhancer binding protein z) recruits METTL3 onto the promoter of oncogenic transcription factors to increase the translational efficiency of the methylated transcripts [67]. In human pluripotent stem cells, SMAD2 and SMAD3 promote the loading of MTC on the pluripotency factor gene NANOG, effectively enabling the degradation of the NANOG transcript and a timely exit from pluripotency [111].

The recruitment of MTC to chromatin is a key regulatory step in the m6A functional cascade, and a group of studies provided new insights on this while reporting on the epigenomic-epitranscriptomic crosstalk. These studies focused on the activity of m6A in gene bodies [85-87], and intergenic loci [79] in mESc and human immune cells.

The study by Liu and colleagues, which unveiled the regulatory role of m6A over LINE1 [79], sought to identify the role of m6A modification of carRNAs (promoterassociated RNAs, enhancer RNAs and repetitive RNAs) in shaping genome-wide chromatin accessibility. The authors found that chromatin accessibility was increased in METTL3 KO (genome-wide), together with the acquisition of the accessible histone marks H3K4me3 and H3K27ac (Figure 1A). METTL3 KO triggered transcription, especially from the genomic loci downstream from intense m6A peaks, and increased the turnover rate of a fraction of the methylated carRNAs, and was mediated by the reader YTHDC1, in conjunction with the nuclear exosome complex (NEXT). Site-directed de-methylation of specific carRNAs by dCas13-FTO in WT mESc recapitulated the effects of METTL3 depletion on histone marks and transcription, thus supporting a role for m6A of carRNAs in repressing chromatin accessibility and transcriptional output [79].

$\mathrm{Li}$ and colleagues subsequently showed that m6A deposition in nascent mRNAs promotes genome-wide de-methylation of the repressive $\mathrm{H} 3 \mathrm{~K} 9 \mathrm{me} 2$, and feedbacks positively on gene expression [85]. The authors collected preliminary evidence of the direct regula- 
tion of m6A over H3K9me2 using a reporter model in HEK293, and later confirmed their findings in mESc. Mechanistically, they found that the nuclear reader YTHDC1 recognised and interacted with m6A-methylated nascent transcripts to recruit lysine demethylase KDM3B (Figure 2A), which in turn demethylated H3K9me2. The findings were supported by targeting dCas13-YTHDC1 on specific genomic loci, where the authors observed an enhanced recruitment of KDM3B and concurrent demethylation of H3K9me2. These data show that m6A of nascent mRNAs can directly promote the de-methylation of histone tails, in order to favour chromatin accessibility and increase the transcriptional output of mRNAs [85]. As observed in the previous study from Liu and colleagues, the reader YTHDC1 appeared to mediate the action of m6A on chromatin accessibility.
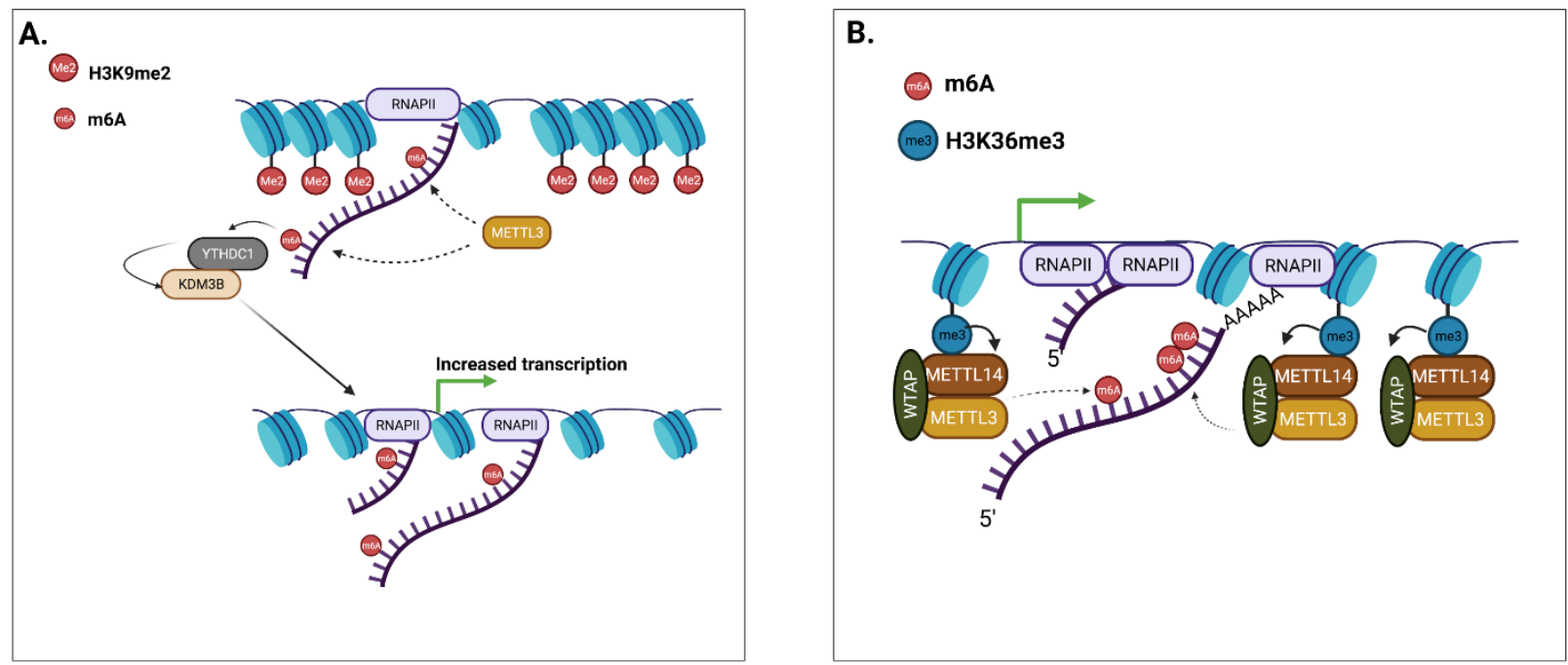

Figure 2. The interplay between histone modifications, gene transcription, and m6A. (A) METTL3dependent methylation of mRNAs recruits YTHDC1, which in turn loads histone demethylase KDM3B to remove histone $\mathrm{H} 3$-lysine9 dimethylation $(\mathrm{H} 3 \mathrm{~K} 9 \mathrm{me} 2)$ and promote gene transcription. (B) Histone H3-lysine36 trimethylation (H3K36me3) recruits the m6A methyltransferase complex onto accessible chromatin, and promotes the methylation of newly transcribed mRNAs. Created with BioRender.com.

While the previous two studies highlighted an active role for m6A and its reader YTHDC1 in guiding histone modifications and chromatin accessibility, albeit with opposite functions, Huang and colleagues described a mechanism where a specific histone modification promotes m6A deposition on nascent RNAs [86]. The authors uncovered the key interaction between the m6A writer METTL14 and H3K36me3, which marks actively transcribed regions. This is key in assuring a functional and possibly physical interaction between MTC and RNA polymerase II. The depletion of H3K36me3 (either by KO of histone lysine methyltransferase SETD2, or overexpression of histone lysine demethylase KDM4A) triggered a reduction in $\mathrm{m} 6 \mathrm{~A}$ levels. This was a unidirectional effect, as the depletion of m6A through METTL14 KD did not alter H3K36me3 levels. The authors confirmed their findings on selected transcripts, such as MYC and ACTB, where guiding of dCas9-KDM4A (MYC) or dCas9-SETDB2 (ACTB) reduced and increased m6A levels, respectively. Biologically, the decrease of m6A, dependent on H3K36me3 depletion, interfered with mESc differentiation, which is consistent with the known role of m6A in promoting pluripotency genes' turnover [71] (Figure 2B).

Finally, $\mathrm{Wu}$ and colleagues reported in human immune cells that histone lysine demethylase KDM6B [87] recruited MTC on specific gene subsets. In a model of infection, the repressive mark H3K27me3 acted as a barrier to m6A modification, and KDM6B acted by demethylating this repressive mark to support the m6A modification of nascent transcripts by recruiting MTC. YTHDF2 negatively regulated the stability of the m6A- 
marked KDM6B transcript. In YTHDF2 KO cells, decreased levels of H3K27me3 led to the up-regulation of cytokine mRNA transcription (Il-6), and also allowed the deposition of m6A on mRNAs coding for histone modifiers, and both actions were mediated by KDM6B. Interestingly, the authors reported that in murine cells, YTHDF2 did not bind to KDM6B mRNA, suggesting that mouse and human RNA targets of this reader might not fully overlap [87].

\section{Summary of: Chromatin Accessibility, Transcriptional Regulation, and $m 6 A$}

While it cannot be excluded that inherent limitations of the experimental approaches (Box 1) could be biasing data interpretation, these works [79,85-87], together with early reports [23,62], build a robust case for considering m6A an integral player in the epigenetic circuit. The ability shown by both reader and writer proteins to interact with epigenetic players, either at the mRNA or protein level, might be the obvious justification for the variety of effects that have been reported. In loci where active transcription takes place, m6A could function by promoting chromatin openness and transcriptional output [85], while in some cases, specific accessible histone marks (H3K36me3) would recruit m6A to provide some form of post-transcriptional control over the transcribed genes, with no direct impact over the local chromatin state [86]. In intergenic regions, however, m6A decorates other classes of RNAs, such as carRNAs, and it appears to repress accessibility and transcription [79]. These interesting observations would suggest that the m6A machinery functionally integrates within the local chromatin context. How this is regulated needs to be clarified, but surely, given the vast amount of coding and non-coding RNAs targeted by $\mathrm{m} 6 \mathrm{~A}$, the active role of $\mathrm{m} 6 \mathrm{~A}$ within both activator and repressive chromatin environments is not surprising. On a higher level of regulation, how the m6A-dependent methylation of nascent transcripts and the m6A-dependent epigenetic regulation of the chromatin state are functionally integrated is still underexplored.

Box 1. Technical approaches to the study of m6A epigenomic crosstalk.

On a technological standpoint, the study of the crosstalk between m6A and the histone signature relies on achieving high resolution mapping of known modifications, both in the genome and in the transcriptome. That is why approaches such as CHIP-Seq (Chromatin ImmunoprecipitationSequencing) to map histone tail modifications and meRIP-Seq (m6A-specific methylated RNA immunoprecipitation-Sequencing) to map m6A on the RNA fraction have been employed by most of the reviewed studies $[62,79,80,82,83,85-87]$. Fractionation approaches aimed at separating the cytoplasm from the nucleus aided in retrieving RNAs specifically associated to the chromatin portion and such RNAs were later analysed either by HPLC-MS (liquid chromatography coupled with mass spectrometry), or by meRIP-seq [79,84-86]. One study [82] attempted the validation of selected methylated adenosines on a target RNA at single nucleotide resolution, by employing SELECT (single-base elongation and single-base ligation qPCR amplification method) [112]: this provides a method for validating methylated residues in support of mechanistic insights. The reviewed studies perturbed the m6A machinery by employing approaches such as genetic knock out, as well as acute depletion via the AID (Auxin Inducible Degron) system of reader and writer proteins. As regards to this, data show that acute depletion methods might aid scientists who wish to focus on a time restricted, dynamic aspect of the epigenomics-epitranscriptomics crosstalk $[79,83]$. In order to gain mechanistic insight, some of the studies investigated the interaction of modified RNAs with the chromatin and their relative genomic location by employing methods such as CHIRP-Seq (Chromatin Isolation by RNA Immunoprecipitation-Sequencing) [80,82], which in one case was validated using a published GRID-Seq (Global RNA Interactions with DNA sequencing) dataset [113]. Finally, the impact of m6A over the activity/fate of selected repetitive elements was validated by targeted RNA de-methylation, using an ALKBH5/FTO enzyme tethered to a dCas13, a very precise method for achieving precise local disruption of the m6A network, without the need for the genetic manipulation of the target transcripts $[79,85]$. A similar method, based on $\mathrm{dCas} 9$ has also been used to guide histone modification proteins or m6A readers to the chromatin region overlapping with $\mathrm{m} 6 \mathrm{~A}$ peaks, to investigate the effect of histone modulation over the local abundance of $\mathrm{m} 6 \mathrm{~A}$ and vice versa [82]. 


\section{4. m6A and Liquid-Liquid Phase Separation}

With regards to the execution of context-specific nuclear functions, an emergent field of investigation is the assembly of membraneless biomolecular condensates via the process of liquid-liquid phase separation (LLPS). Biomolecular condensates are made of a liquid and a dense phase, where the dense phase acts by concentrating and organising functionally related molecules to support the execution of biological processes [114]. The maintenance of the genomic structure and its function in the nucleus depends on the structural organisation provided by LLPS [115]; in fact, the occurrence of LLPS is key in physiological [116] and diseased states [117]. RNAs are key triggers of LLPS, and features such as their nucleotide composition, length, structure, and expression levels all affect physical properties of the membraneless condensates [118].

RNA modifications can affect LLPS in the cytoplasm, as m6A-marked mRNAs are sorted to stress granules, p-bodies, and neural mRNA granules through the binding of cytoplasmic YTHDF readers [119]. An important feature of mRNAs that favours LLPS is the occurrence of clusters of methylated nucleotides in a single mRNA molecule, which increases the likelihood of its separation in dense droplets through the recruitment of multiple YTHDF readers [119-121]. In addition to YTHDFs, the nuclear reader YTHDC1 has also recently been observed to undergo LLPS in human myeloid leukaemia cells [122]. According to this study, m6A and YTHDC1 appear to support the cancerous phenotype of AML cells by forming nuclear condensates (nYACs) that protect the mRNAs' coding for oncogenes from degradation by the PAXT (polyA tail exosome) complex. Interestingly, nYACs seem to preferentially occur in AML cells as opposed to non-leukemic hematopoietic cells, and their formation is dependent on the presence of an N-terminal IDR (intrinsically disordered region) on the YTHDC1 protein [122].

Overall, there is growing evidence that RNA m6A is a positive regulator of LLPS, and that it can promote the assembly of YTHDC1 biomolecular condensates in the nucleus. Based on the data reviewed here, it is tempting to speculate that m6A of chromatinassociated RNAs could be driving LLPS of epigenetic regulators, both in euchromatin and heterochromatin domains.

\section{Conclusions}

These exciting novel data unveil a previously unappreciated crosstalk between epitranscriptomics and epigenomics and pose the foundation for its deeper investigation, especially in human cellular models. The future studies of such crosstalk will improve our understanding of how the m6A modification of RNA integrates in the nuclear regulatory mechanism, and will hopefully provide new insights on how to modulate gene expression, either experimentally or therapeutically.

Author Contributions: Conceptualization, T.S.; writing-original draft preparation, T.S.; writingreview and editing, T.S. and C.L. All authors have read and agreed to the published version of the manuscript.

Funding: This research received no external funding.

Institutional Review Board Statement: Not applicable.

Informed Consent Statement: Not applicable.

Data Availability Statement: Not applicable.

Acknowledgments: The authors acknowledgeIstituto di Tecnologie Biomediche, Consiglio Nazionale delle Ricerche for covering the publication costs.

Conflicts of Interest: The authors declare no conflict of interest. 


\section{References}

1. Boccaletto, P.; Machnicka, M.A.; Purta, E.; Piątkowski, P.; Baginski, B.; Wirecki, T.K.; de Crécy-Lagard, V.; Ross, R.; Limbach, P.A.; Kotter, A.; et al. MODOMICS: A database of RNA modification pathways. 2017 update. Nucleic Acids Res. 2018, 46, D303-D307. [CrossRef]

2. Liu, N.; Dai, Q.; Zheng, G.; He, C.; Parisien, M.; Pan, T. $N^{6}$-methyladenosine-dependent RNA structural switches regulate RNA-protein interactions. Nature 2015, 518, 560-564. [CrossRef]

3. Wiener, D.; Schwartz, S. The epitranscriptome beyond m6A. Nat. Rev. Genet. 2021, 22, 119-131. [CrossRef]

4. Khoddami, V.; Yerra, A.; Mosbruger, T.L.; Fleming, A.M.; Burrows, C.J.; Cairns, B.R. Transcriptome-wide profiling of multiple RNA modifications simultaneously at single-base resolution. Proc. Natl. Acad. Sci. USA 2019, 116, 6784-6789. [CrossRef]

5. Jonkhout, N.; Tran, J.; Smith, M.; Schonrock, N.; Mattick, J.; Novoa, E.M. The RNA modification landscape in human disease. RNA 2017, 23, 1754-1769. [CrossRef]

6. Barbieri, I.; Kouzarides, T. Role of RNA modifications in cancer. Nat. Rev. Cancer 2020, 20, 303-322. [CrossRef]

7. Perry, R.P.; Kelley, D.E.; Friderici, K.; Rottman, F. The methylated constituents of L cell messenger RNA: Evidence for an unusual cluster at the $5^{\prime}$ terminus. Cell 1975, 4, 387-394. [CrossRef]

8. Desrosiers, R.; Friderici, K.; Rottman, F. Identification of methylated nucleosides in messenger RNA from Novikoff hepatoma cells. Proc. Natl. Acad. Sci. USA 1974, 71, 3971-3975. [CrossRef]

9. Dominissini, D.; Moshitch-Moshkovitz, S.; Schwartz, S.; Salmon-Divon, M.; Ungar, L.; Osenberg, S.; Cesarkas, K.; Jacob-Hirsch, J.; Amariglio, N.; Kupiec, M.; et al. Topology of the human and mouse m6A RNA methylomes revealed by m6A-seq. Nature 2012, 485, 201-206. [CrossRef]

10. Meyer, K.D.; Saletore, Y.; Zumbo, P.; Elemento, O.; Mason, C.E.; Jaffrey, S.R. Comprehensive analysis of mRNA methylation reveals enrichment in $3^{\prime}$ utrs and near stop codons. Cell 2012, 149, 1635-1646. [CrossRef]

11. Linder, B.; Grozhik, A.V.; Olarerin-George, A.O.; Meydan, C.; Mason, C.E.; Jaffrey, S.R. Single-nucleotide-resolution mapping of m6A and m6Am throughout the transcriptome. Nat. Methods 2015, 12, 767-772. [CrossRef]

12. Slobodin, B.; Han, R.; Calderone, V.; Vrielink, J.A.F.O.; Loayza-Puch, F.; Elkon, R.; Agami, R. Transcription impacts the effi-ciency of MRNA translation via co-transcriptional $N^{6}$-adenosine methylation. Cell 2017, 169, 326-337.e12. [CrossRef]

13. Knuckles, P.; Carl, S.H.; Musheev, M.; Niehrs, C.; Wenger, A.; Bühler, M. RNA fate determination through cotranscriptional adenosine methylation and microprocessor binding. Nat. Struct. Mol. Biol. 2017, 24, 561-569. [CrossRef]

14. Liu, J.; Yue, Y.; Han, D.; Wang, X.; Fu, Y.; Zhang, L.; Jia, G.; Yu, M.; Lu, Z.; Deng, X.; et al. A METTL3-METTL14 complex mediates mammalian nuclear RNA $N^{6}$-adenosine methylation. Nat. Chem. Biol. 2014, 10, 93-95. [CrossRef]

15. Lin, Z.; Hsu, P.; Xing, X.; Fang, J.; Lu, Z.; Zou, Q.; Zhang, K.-J.; Zhang, X.; Zhou, Y.; Zhang, T.; et al. Mettl3-/Mettl14-mediated mRNA $N^{6}$-methyladenosine modulates murine spermatogenesis. Cell Res. 2017, 27, 1216-1230. [CrossRef]

16. Wang, P.; Doxtader, K.; Nam, Y. Structural basis for cooperative function of Mettl3 and Mettl14 methyltransferases. Mol. Cell 2016, 63, 306-317. [CrossRef]

17. Ping, X.-L.; Sun, B.-F.; Wang, L.; Xiao, W.; Yang, X.; Wang, W.-J.; Adhikari, S.; Shi, Y.; Lv, Y.; Chen, Y.-S.; et al. Mammalian WTAP is a regulatory subunit of the RNA $N^{6}$-methyladenosine methyltransferase. Cell Res. 2014, 24, 177-189. [CrossRef]

18. Yue, Y.; Liu, J.; Cui, X.; Cao, J.; Luo, G.; Zhang, Z.; Cheng, T.; Gao, M.; Shu, X.; Ma, H.; et al. VIRMA mediates preferential m6A mRNA methylation in $3^{\prime}$ UTR and near stop codon and associates with alternative polyadenylation. Cell Discov. 2018, 4. [CrossRef]

19. Knuckles, P.; Lence, T.; Haussmann, I.U.; Jacob, D.; Kreim, N.; Carl, S.H.; Masiello, I.; Hares, T.; Villaseñor, R.; Hess, D.; et al. Zc3h13/Flacc is required for adenosine methylation by bridging the MRNA-binding factor Rbm15/Spenito to the m6A machinery component Wtap/ Fl(2)d. Genes Dev. 2018, 32, 415-429. [CrossRef]

20. Wen, J.; Lv, R.; Ma, H.; Shen, H.; He, C.; Wang, J.; Jiao, F.; Liu, H.; Yang, P.; Tan, L.; et al. Zc3h13 regulates nuclear RNA m6A methylation and mouse embryonic stem cell self-renewal. Mol. Cell 2018, 69, 1028-1038.e6. [CrossRef]

21. Geula, S.; Moshitch-Moshkovitz, S.; Dominissini, D.; Mansour, A.A.; Kol, N.; Salmon-Divon, M.; Hershkovitz, V.; Peer, E.; Mor, N.; Manor, Y.S.; et al. M6A mRNA methylation facilitates resolution of naïve pluripotency toward differentiation. Science 2015, 347, 1002-1006. [CrossRef]

22. Alarcón, C.R.; Goodarzi, H.; Lee, H.; Liu, X.; Tavazoie, S.; Tavazoie, S.F. HNRNPA2B1 is a mediator of m6A-dependent nuclear RNA processing events. Cell 2015, 162, 1299-1308. [CrossRef]

23. Patil, D.P.; Chen, C.-K.; Pickering, B.F.; Chow, A.; Jackson, C.; Guttman, M.; Jaffrey, S.R. M6A RNA methylation promotes XIST-mediated transcriptional repression. Nature 2016, 537, 369-373. [CrossRef]

24. Yang, D.; Qiao, J.; Wang, G.; Lan, Y.; Li, G.; Guo, X.; Xi, J.; Ye, D.; Zhu, S.; Chen, W.; et al. $N^{6}$-methyladenosine modification of LincRNA 1281 is critically required for mESC differentiation potential. Nucleic Acids Res. 2018, 46, 3906-3920. [CrossRef]

25. Warda, A.S.; Kretschmer, J.; Hackert, P.; Lenz, C.; Urlaub, H.; Höbartner, C.; Sloan, K.E.; Bohnsack, M.T. Human METTL16 is a $N^{6}$-methyladenosine (m6A) methyltransferase that targets pre-MRNAs and various non-coding RNAs. EMBO Rep. 2017, 18, 2004-2014. [CrossRef]

26. Pendleton, K.E.; Chen, B.; Liu, K.; Hunter, O.V.; Xie, Y.; Tu, B.P.; Conrad, N.K. The U6 snRNA m 6 A methyltransferase METTL16 regulates SAM synthetase intron retention. Cell 2017, 169, 824-835.e14. [CrossRef]

27. Brown, J.A.; Kinzig, C.G.; DeGregorio, S.J.; Steitz, J.A. Methyltransferase-like protein 16 binds the $3^{\prime}$-terminal triple helix of MALAT1 long noncoding RNA. Proc. Natl. Acad. Sci. USA 2016, 113, 14013-14018. [CrossRef] 
28. Ruszkowska, A. METTL16, methyltransferase-like protein 16: Current insights into structure and function. Int. J. Mol. Sci. 2021, 22, 2176. [CrossRef]

29. Mendel, M.; Chen, K.-M.; Homolka, D.; Gos, P.; Pandey, R.R.; McCarthy, A.A.; Pillai, R.S. Methylation of structured RNA by the m6A writer METTL16 is essential for mouse embryonic development. Mol. Cell 2018, 71, 986-1000.e11. [CrossRef]

30. Xu, C.; Wang, X.; Liu, K.; Roundtree, I.A.; Tempel, W.; Li, Y.; Lu, Z.; He, C.; Min, J. Structural basis for selective binding of m6A RNA by the YTHDC1 YTH domain. Nat. Chem. Biol. 2014, 10, 927-929. [CrossRef]

31. Zhang, Z.; Theler, D.; Kaminska, K.H.; Hiller, M.; de la Grange, P.; Pudimat, R.; Rafalska, I.; Heinrich, B.; Bujnicki, J.M.; Allain, F.H.-T.; et al. The YTH domain is a novel RNA binding domain. J. Biol. Chem. 2010, 285, 14701-14710. [CrossRef]

32. Xiao, W.; Adhikari, S.; Dahal, U.; Chen, Y.-S.; Hao, Y.-J.; Sun, B.-F.; Sun, H.-Y.; Li, A.; Ping, X.-L.; Lai, W.-Y.; et al. Nuclear m6A reader YTHDC1 regulates mRNA splicing. Mol. Cell 2016, 61, 507-519. [CrossRef]

33. Roundtree, I.A.; Luo, G.-Z.; Zhang, Z.; Wang, X.; Zhou, T.; Cui, Y.; Sha, J.; Huang, X.; Guerrero, L.; Xie, P.; et al. YTHDC1 mediates nuclear export of $N^{6}$-methyladenosine methylated mRNAs. eLife 2017, 6, e31311. [CrossRef]

34. Wojtas, M.N.; Pandey, R.R.; Mendel, M.; Homolka, D.; Sachidanandam, R.; Pillai, R.S. Regulation of m6A transcripts by the $3^{\prime} \rightarrow 5^{\prime}$ RNA helicase YTHDC2 is essential for a successful meiotic program in the mammalian germline. Mol. Cell 2017, 68, 374-387.e12. [CrossRef]

35. Kasowitz, S.; Ma, J.; Anderson, S.J.; Leu, N.A.; Xu, Y.; Gregory, B.D.; Schultz, R.M.; Wang, P.J. Nuclear m6A reader YTHDC1 regulates alternative polyadenylation and splicing during mouse oocyte development. PLoS Genet. 2018, 14, e1007412. [CrossRef]

36. Hsu, P.; Zhu, Y.; Ma, H.; Guo, Y.; Shi, X.; Liu, Y.; Qi, M.; Lu, Z.; Shi, H.; Wang, J.; et al. Ythdc2 is an N ${ }^{6}$-methyladenosine binding protein that regulates mammalian spermatogenesis. Cell Res. 2017, 27, 1115-1127. [CrossRef]

37. Wang, X.; Lu, Z.; Gomez, A.; Hon, G.C.; Yue, Y.; Han, D.; Fu, Y.; Parisien, M.; Dai, Q.; Jia, G.; et al. N6-methyladenosine-dependent regulation of messenger RNA stability. Nature 2014, 505, 117-120. [CrossRef]

38. Shi, H.; Wang, X.; Lu, Z.; Zhao, B.S.; Ma, H.; Hsu, P.J.; Liu, C.; He, C. YTHDF3 facilitates translation and decay of N6. methyladenosine-modified RNA. Cell Res. 2017, 27, 315-328. [CrossRef]

39. Lasman, L.; Krupalnik, V.; Viukov, S.; Mor, N.; Aguilera-Castrejon, A.; Schneir, D.; Bayerl, J.; Mizrahi, O.; Peles, S.; Tawil, S.; et al. Context-dependent functional compensation between Ythdf m6A reader proteins. Genes Dev. 2020, 34, 1373-1391. [CrossRef]

40. Zaccara, S.; Jaffrey, S.R. A unified model for the function of YTHDF proteins in regulating m6A-modified mRNA. Cell 2020, 181, 1582-1595.e18. [CrossRef]

41. Liu, N.; Zhou, K.; Parisien, M.; Dai, Q.; Diatchenko, L.; Pan, T. N 6-methyladenosine alters RNA structure to regulate binding of a low-complexity protein. Nucleic Acids Res. 2017, 45, 6051-6063. [CrossRef] [PubMed]

42. Huang, H.; Weng, H.; Sun, W.; Qin, X.; Shi, H.; Wu, H.; Zhao, B.S.; Mesquita, A.; Liu, C.; Yuan, C.L.; et al. Recognition of RNA $N^{6}$-methyladenosine by IGF2BP proteins enhances mRNA stability and translation. Nat. Cell Biol. 2020, 20, 285-295. [CrossRef] [PubMed]

43. Sanchez de Groot, N.; Armaos, A.; Graña-Montes, R.; Alriquet, M.; Calloni, G.; Vabulas, R.M.; Tartaglia, G.G. RNA structure drives interaction with proteins. Nat. Commun. 2019, 10. [CrossRef] [PubMed]

44. Roost, C.; Lynch, S.R.; Batista, P.J.; Qu, K.; Chang, H.Y.; Kool, E.T. Structure and thermodynamics of $N^{6}-$ methyladenosine in RNA: A spring-loaded base modification. J. Am. Chem. Soc. 2015, 137, 2107-2115. [CrossRef]

45. Edupuganti, R.R.; Geiger, S.; Lindeboom, R.G.H.; Shi, H.; Hsu, P.J.; Lu, Z.; Wang, S.-Y.; Baltissen, M.P.A.; Jansen, P.W.T.C.; Rossa, M.; et al. $N^{6}$-methyladenosine (m6A) recruits and repels proteins to regulate mRNA homeostasis. Nat. Struct. Mol. Biol. 2017, 24, 870-878. [CrossRef]

46. Fedeles, B.I.; Singh, V.; Delaney, J.C.; Li, D.; Essigmann, J.M. The AlkB family of Fe(II)/ $\alpha$-Ketoglutarate-dependent dioxygenases: Repairing nucleic acid alkylation damage and beyond. J. Biol. Chem. 2015, 290, 20734-20742. [CrossRef]

47. Zheng, G.; Dahl, J.A.; Niu, Y.; Fedorcsak, P.; Huang, C.-M.; Li, C.J.; Vågbø, C.B.; Shi, Y.; Wang, W.-L.; Song, S.-H.; et al. ALKBH5 is a mammalian RNA demethylase that impacts RNA metabolism and mouse fertility. Mol. Cell 2013, 49, 18-29. [CrossRef]

48. Zhang, C.; Samanta, D.; Lu, H.; Bullen, J.W.; Zhang, H.; Chen, I.; He, X.; Semenza, G.L. Hypoxia induces the breast cancer stem cell phenotype by HIF-dependent and ALKBH5-mediated m6A-demethylation of NANOG mRNA. Proc. Natl. Acad. Sci. USA 2016, 113, E2047-E2056. [CrossRef]

49. Jia, G.; Fu, Y.; Zhao, X.; Dai, Q.; Zheng, G.; Yang, Y.; Yi, C.; Lindahl, T.; Pan, T.; Yang, Y.-G.; et al. N ${ }^{6}$-methyladenosine in nuclear RNA is a major substrate of the obesity-associated FTO. Nat. Chem. Biol. 2011, 7, 885-887. [CrossRef]

50. Mauer, J.; Sindelar, M.; Despic, V.; Guez, T.; Hawley, B.R.; Vasseur, J.-J.; Rentmeister, A.; Gross, S.S.; Pellizzoni, L.; Debart, F.; et al. FTO controls reversible m6Am RNA methylation during snRNA biogenesis. Nat. Chem. Biol. 2019, 15, 340-347. [CrossRef]

51. Bartosovic, M.; Molares, H.C.; Gregorova, P.; Hrossova, D.; Kudla, G.; Vanacova, S. $N^{6}$-methyladenosine demethylase FTO targets pre-MRNAs and regulates alternative splicing and 3'-end processing. Nucleic Acids Res. 2017, 45, 11356-11370. [CrossRef] [PubMed]

52. Li, Z.; Weng, H.; Su, R.; Weng, X.; Zuo, Z.; Li, C.; Huang, H.; Nachtergaele, S.; Dong, L.; Hu, C.; et al. FTO plays an oncogenic role in acute myeloid leukemia as a $N^{6}$-methyladenosine RNA demethylase. Cancer Cell 2017, 31, 127-141. [CrossRef] [PubMed]

53. Sommer, S.; Lavi, U.; Darnell, J.E. The absolute frequency of labeled N-6-methyladenosine in HeLa cell messenger RNA decreases with label time. J. Mol. Biol. 1978, 124, 487-499. [CrossRef]

54. Wang, Y.; Li, Y.; Toth, J.I.; Petroski, M.D.; Zhang, Z.; Zhao, J.C. $N^{6}$-methyladenosine modification destabilizes developmental regulators in embryonic stem cells. Nat. Cell Biol. 2014, 16, 191-198. [CrossRef] [PubMed] 
55. Batista, P.J.; Molinie, B.; Wang, J.; Qu, K.; Zhang, J.; Li, L.; Bouley, D.M.; Lujan, E.; Haddad, B.; Daneshvar, K.; et al. M6A RNA modification controls cell fate transition in mammalian embryonic stem cells. Cell Stem Cell 2014, 15, 707-719. [CrossRef] [PubMed]

56. Wang, X.; Zhao, B.; Roundtree, I.A.; Lu, Z.; Han, D.; Ma, H.; Weng, X.; Chen, K.; Shi, H.; He, C. N ${ }^{6}$-methyladenosine modulates messenger RNA translation efficiency. Cell 2015, 161, 1388-1399. [CrossRef]

57. Meyer, K.D.; Patil, D.P.; Zhou, J.; Zinoviev, A.; Skabkin, M.A.; Elemento, O.; Pestova, T.V.; Qian, S.-B.; Jaffrey, S.R. 5’ UTR m(6)A promotes cap-independent translation. Cell 2015, 163, 999-1010. [CrossRef]

58. Zhou, J.; Wan, J.; Gao, X.; Zhang, X.; Jaffrey, S.R.; Qian, S.-B. Dynamic m6A mRNA methylation directs translational control of heat shock response. Nature 2015, 526, 591-594. [CrossRef]

59. Zhao, X.; Yang, Y.; Sun, B.-F.; Shi, Y.; Yang, X.; Xiao, W.; Hao, Y.-J.; Ping, X.-L.; Chen, Y.-S.; Wang, W.-J.; et al. FTO-dependent demethylation of $N^{6}$-methyladenosine regulates mRNA splicing and is required for adipogenesis. Cell Res. 2014, 24, 1403-1419. [CrossRef]

60. Ivanova, I.; Much, C.; di Giacomo, M.; Azzi, C.; Morgan, M.; Moreira, P.N.; Monahan, J.; Carrieri, C.; Enright, A.J.; O'Carroll, D. The RNA m6A reader YTHDF2 is essential for the post-transcriptional regulation of the maternal transcriptome and oocyte competence. Mol. Cell 2017, 67, 1059-1067.e4. [CrossRef]

61. Edens, B.M.; Vissers, C.; Su, J.; Arumugam, S.; Xu, Z.; Shi, H.; Miller, N.; Ringeling, F.R.; Ming, G.-L.; He, C.; et al. FMRP modulates neural differentiation through m6A-dependent mRNA nuclear export. Cell Rep. 2019, 28, 845-854.e5. [CrossRef] [PubMed]

62. Wang, Y.; Li, Y.; Yue, M.; Wang, J.; Kumar, S.; Wechsler-Reya, R.J.; Zhang, Z.; Ogawa, Y.; Kellis, M.; Duester, G.; et al. N $N^{6}$ methyladenosine RNA modification regulates embryonic neural stem cell self-renewal through histone modifications. Nat. Neurosci. 2018, 21, 195-206. [CrossRef] [PubMed]

63. Li, M.; Zhao, X.; Wang, W.; Shi, H.; Pan, Q.; Lu, Z.; Perez, S.P.; Suganthan, R.; He, C.; Bjørås, M.; et al. Ythdf2-mediated m6A mRNA clearance modulates neural development in mice. Genome Biol. 2018, 19. [CrossRef] [PubMed]

64. Fustin, J.-M.; Doi, M.; Yamaguchi, Y.; Hida, H.; Nishimura, S.; Yoshida, M.; Isagawa, T.; Morioka, M.S.; Kakeya, H.; Manabe, I.; et al. RNA-methylation-dependent RNA processing controls the speed of the circadian clock. Cell 2013, 155, 793-806. [CrossRef] [PubMed]

65. Min, K.-W.; Zealy, R.W.; Davila, S.; Fomin, M.; Cummings, J.C.; Makowsky, D.; Mcdowell, C.H.; Thigpen, H.; Hafner, M.; Kwon, S.-H.; et al. Profiling of m6A RNA modifications identified an age-associated regulation of AGO2 mRNA stability. Aging Cell 2018, 17, e12753. [CrossRef]

66. Liu, J.; Eckert, M.A.; Harada, B.T.; Liu, S.-M.; Lu, Z.; Yu, K.; Tienda, S.M.; Chryplewicz, A.; Zhu, A.C.; Yang, Y.; et al. M6A mRNA methylation regulates AKT activity to promote the proliferation and tumorigenicity of endometrial cancer. Nat. Cell Biol. 2018, 20, 1074-1083. [CrossRef]

67. Barbieri, I.; Tzelepis, K.; Pandolfini, L.; Namshik, H.; Millan-Zambrano, G.; Robson, S.C.; Aspris, D.; Migliori, V.; Bannister, A.J.; Hannes, P.; et al. Promoter-bound METTL3 maintains myeloid leukaemia by m6A-dependent translation control. Nature 2017, 552, 126-131. [CrossRef]

68. Lin, X.; Chai, G.; Wu, Y.; Li, J.; Chen, F.; Liu, J.; Luo, G.; Tauler, J.; Du, J.; Lin, S.; et al. RNA m6A methylation regulates the epithelial mesenchymal transition of cancer cells and translation of snail. Nat. Commun. 2019, 10. [CrossRef]

69. Lin, S.; Choe, J.; Du, P.; Triboulet, R.; Gregory, R.I. The m6A methyltransferase METTL3 promotes translation in human cancer cells. Mol. Cell 2016, 62, 335-345. [CrossRef]

70. Yang, S.; Wei, J.; Cui, Y.-H.; Park, G.; Shah, P.; Deng, Y.; Aplin, A.E.; Lu, Z.; Hwang, S.; He, C.; et al. m ${ }^{6}$ A mRNA demethylase FTO regulates melanoma tumorigenicity and response to anti-PD-1 blockade. Nat. Commun. 2019, 10, 2782. [CrossRef]

71. Huang, H.; Weng, H.; Chen, J. M6A modification in coding and non-coding RNAs: Roles and therapeutic implications in cancer. Cancer Cell 2020, 37, 270-288. [CrossRef] [PubMed]

72. Vu, L.P.; Pickering, B.F.; Cheng, Y.; Zaccara, S.; Nguyen, D.; Minuesa, G.; Chou, T.; Chow, A.; Saletore, Y.; Mackay, M.; et al. The $N^{6}$-methyladenosine (m6A)-forming enzyme METTL3 controls myeloid differentiation of normal hematopoietic and leukemia cells. Nat. Med. 2017, 23, 1369-1376. [CrossRef] [PubMed]

73. Han, D.; Liu, J.; Chen, C.; Dong, L.; Liu, Y.; Chang, R.; Huang, X.; Liu, Y.; Wang, J.; Dougherty, U.; et al. Anti-tumour immunity controlled through MRNA m6A methylation and YTHDF1 in dendritic cells. Nature 2019, 566, 270-274. [CrossRef] [PubMed]

74. Song, H.; Song, J.; Cheng, M.; Zheng, M.; Wang, T.; Tian, S.; Flavell, R.A.; Zhu, S.; Li, H.-B.; Ding, C.; et al. METTL3-mediated m6 A RNA methylation promotes the anti-tumour immunity of natural killer cells. Nat. Commun. 2021, 12, 5522. [CrossRef] [PubMed]

75. Schaefer, M. The regulation of RNA modification systems: The next frontier in epitranscriptomics? Genes 2021, 12, 345. [CrossRef]

76. Porman, A.M.; Roberts, J.T.; Duncan, E.D.; Chrupcala, M.L.; Levine, A.A.; Kennedy, M.A.; Williams, M.M.; Richer, J.K.; Johnson, A.M. A single $N^{6}$-methyladenosine site in LncRNA HOTAIR regulates its function in breast cancer cells. bioRxiv 2021. Available online: https:/ / www.biorxiv.org/content/10.1101/2020.06.08.140954v3 (accessed on 29 December 2021). [CrossRef]

77. Kan, R.L.; Chen, J.; Sallam, T. Crosstalk between epitranscriptomic and epigenetic mechanisms in gene regulation. Trends Genet. 2021, 38, 182-193. [CrossRef]

78. Zhao, Y.; Chen, Y.; Jin, M.; Wang, J. The crosstalk between m6A RNA methylation and other epigenetic regulators: A novel perspective in epigenetic remodeling. Theranostics 2021, 11, 4549-4566. [CrossRef] 
79. Liu, J.; Dou, X.; Chen, C.; Chen, C.; Liu, C.; Xu, M.M.; Zhao, S.; Shen, B.; Gao, Y.; Han, D.; et al. N 6-methyladenosine of chromosome-associated regulatory RNA regulates chromatin state and transcription. Science 2020, 367, 580-586. [CrossRef]

80. Liu, J.; Gao, M.; He, J.; Wu, K.; Lin, S.; Jin, L.; Chen, Y.; Liu, H.; Shi, J.; Wang, X.; et al. The RNA m6A reader YTHDC1 silences retrotransposons and guards ES cell identity. Nature 2021, 591, 322-326. [CrossRef]

81. Chen, C.; Liu, W.; Guo, J.; Liu, Y.; Liu, X.; Liu, J.; Dou, X.; Le, R.; Huang, Y.; Li, C.; et al. Nuclear m6A reader YTHDC1 regulates the scaffold function of LINE1 RNA in mouse ESCs and early embryos. Protein Cell 2021, 12, 455-474. [CrossRef] [PubMed]

82. Xu, W.; Li, J.; He, C.; Wen, J.; Ma, H.; Rong, B.; Diao, J.; Wang, L.; Wang, J.; Wu, F.; et al. METTL3 regulates heterochromatin in mouse embryonic stem cells. Nature 2021, 591, 317-321. [CrossRef] [PubMed]

83. Chelmicki, T.; Roger, E.; Teissandier, A.; Dura, M.; Bonneville, L.; Rucli, S.; Dossin, F.; Fouassier, C.; Lameiras, S.; Bourc'His, D. M6A RNA methylation regulates the fate of endogenous retroviruses. Nature 2021, 591, 312-316. [CrossRef] [PubMed]

84. Duda, K.J.; Ching, R.W.; Jerabek, L.; Shukeir, N.; Erikson, G.; Engist, B.; Onishi-Seebacher, M.; Perrera, V.; Richter, F.; Mittler, G.; et al. M6A RNA methylation of major satellite repeat transcripts facilitates chromatin association and RNA:DNA hybrid formation in mouse heterochromatin. Nucleic Acids Res. 2021, 49, 5568-5587. [CrossRef] [PubMed]

85. Li, Y.; Xia, L.; Tan, K.; Ye, X.; Zuo, Z.; Li, M.; Xiao, R.; Wang, Z.; Liu, X.; Deng, M.; et al. N $N^{6}$-Methyladenosine co-transcriptionally directs the demethylation of histone H3K9me2. Nat. Genet. 2020, 52, 870-877. [CrossRef]

86. Huang, H.; Weng, H.; Zhou, K.; Wu, T.; Zhao, B.S.; Sun, M.; Chen, Z.; Deng, X.; Xiao, G.; Auer, F.; et al. Histone H3 tri-methylation at lysine 36 guides m6A RNA modification co-transcriptionally. Nature 2019, 567, 414-419. [CrossRef]

87. Wu, C.; Chen, W.; He, J.; Jin, S.; Liu, Y.; Yi, Y.; Gao, Z.; Yang, J.; Yang, J.; Cui, J.; et al. Interplay of m6A and H3K27 trimethylation restrains inflammation during bacterial infection. Sci. Adv. 2020, 6, eaba0647. [CrossRef]

88. Padeken, J.; Zeller, P.; Gasser, S.M. Repeat DNA in genome organization and stability. Curr. Opin. Genet. Dev. 2015, 31, 12-19. [CrossRef]

89. Sassaman, D.M.; Dombroski, B.A.; Moran, J.V.; Kimberland, M.L.; Naas, T.P.; DeBerardinis, R.J.; Gabriel, A.; Swergold, G.D.; Kazazian, H.H., Jr. Many human L1 elements are capable of retrotransposition. Nat. Genet. 1997, 16, 37-43. [CrossRef]

90. Platt, R.N.; Vandewege, M.W.; Ray, D.A. Mammalian transposable elements and their impacts on genome evolution. Chromosom. Res. 2018, 26, 25-43. [CrossRef]

91. Diehl, A.G.; Ouyang, N.; Boyle, A.P. Transposable elements contribute to cell and species-specific chromatin looping and gene regulation in mammalian genomes. Nat. Commun. 2020, 11, 1796. [CrossRef]

92. Horváth, V.; Merenciano, M.; González, J. Revisiting the relationship between transposable elements and the eukaryotic stress response. Trends Genet. 2017, 33, 832-841. [CrossRef] [PubMed]

93. Phalke, S.; Nickel, O.; Walluscheck, D.; Hortig, F.; Onorati, M.C.; Reuter, G. Retrotransposon silencing and telomere integrity in somatic cells of drosophila depends on the cytosine-5 methyltransferase DNMT2. Nat. Genet. 2009, 41, 696-702. [CrossRef] [PubMed]

94. Genenncher, B.; Durdevic, Z.; Hanna, K.; Zinkl, D.; Mobin, M.B.; Senturk, N.; da Silva, B.; Legrand, C.; Carré, C.; Lyko, F.; et al. Mutations in cytosine- 5 tRNA methyltransferases impact mobile element expression and genome stability at specific DNA repeats. Cell Rep. 2018, 22, 1861-1874. [CrossRef] [PubMed]

95. Jachowicz, J.; Bing, X.; Pontabry, J.; Bošković, A.; Rando, O.J.; Torres-Padilla, M.-E. LINE-1 activation after fertilization regulates global chromatin accessibility in the early mouse embryo. Nat. Genet. 2017, 49, 1502-1510. [CrossRef]

96. Percharde, M.; Lin, C.J.; Yin, Y.; Guan, J.; Peixoto, G.A.; Bulut-Karslioglu, A.; Biechele, S.; Huang, B.; Shen, X.; Ramalho-Santos, M. A LINE1-nucleolin partnership regulates early development and ESC identity. Cell 2018, 174, 391-405.e19. [CrossRef]

97. Walter, M.; Teissandier, A.; Pérez-Palacios, R.; Bourc'his, D. An epigenetic switch ensures transposon repression upon dy-namic loss of DNA methylation in embryonic stem cells. eLife 2016, 5, e11418. [CrossRef]

98. Hutnick, L.K.; Huang, X.; Loo, T.-C.; Ma, Z.; Fan, G. Repression of retrotransposal elements in mouse embryonic stem cells is primarily mediated by a DNA methylation-independent mechanism. J. Biol. Chem. 2010, 285, 21082-21091. [CrossRef]

99. Rowe, H.; Jakobsson, J.; Mesnard, D.; Rougemont, J.; Reynard, S.; Aktas, T.; Maillard, P.V.; Layard-Liesching, H.; Verp, S.; Marquis, J.; et al. KAP1 controls endogenous retroviruses in embryonic stem cells. Nature 2010, 463, 237-240. [CrossRef]

100. Janssen, A.; Colmenares, S.U.; Karpen, G.H. Heterochromatin: Guardian of the genome. Annu. Rev. Cell Dev. Biol. 2018, 34, 265-288. [CrossRef]

101. Johnson, W.L.; Yewdell, W.T.; Bell, J.C.; McNulty, S.M.; Duda, Z.; O’Neill, R.J.; A Sullivan, B.; Straight, A.F. RNA-dependent stabilization of SUV39H1 at constitutive heterochromatin. eLife 2017, 6, 25299. [CrossRef]

102. Camacho, O.V.; Galan, C.; Swist-Rosowska, K.; Ching, R.; Gamalinda, M.; Karabiber, F.; de la Rosa-Velazquez, I.; Engist, B.; Koschorz, B.; Shukeir, N.; et al. Major satellite repeat RNA stabilize heterochromatin retention of Suv39h enzymes by RNA-nucleosome association and RNA: DNA hybrid formation. eLife 2017, 6, e25293. [CrossRef] [PubMed]

103. Skourti-Stathaki, K.; Proudfoot, N.J. A double-edged sword: R loops as threats to genome integrity and powerful regulators of gene expression. Genes Dev. 2014, 28, 1384-1396. [CrossRef] [PubMed]

104. Zhang, C.; Chen, L.; Peng, D.; Jiang, A.; He, Y.; Zeng, Y.; Xie, C.; Zhou, H.; Luo, X.; Liu, H.; et al. METTL3 and $N^{6}$-methyladenosine promote homologous recombination-mediated repair of DSBs by modulating DNA-RNA hybrid accumulation. Mol. Cell 2020, 79, 425-442.e7. [CrossRef] [PubMed]

105. Abakir, A.; Giles, T.C.; Cristini, A.; Foster, J.M.; Dai, N.; Starczak, M.; Rubio-Roldan, A.; Li, M.; Eleftheriou, M.; Crutchley, J.; et al. $N^{6}$-methyladenosine regulates the stability of RNA: DNA hybrids in human cells. Nat. Genet. 2019, 52, 48-55. [CrossRef] 
106. Cheng, J.X.; Chen, L.; Li, Y.; Cloe, A.; Yue, M.; Wei, J.; Watanabe, K.A.; Shammo, J.M.; Anastasi, J.; Shen, Q.J.; et al. RNA Cytosine methylation and methyltransferases mediate chromatin organization and 5-azacytidine response and resistance in leukaemia. Nat. Commun. 2018, 9, 1163. [CrossRef]

107. Aguilo, F.; Li, S.; Balasubramaniyan, N.; Sancho, A.; Benko, S.; Zhang, F.; Vashisht, A.; Rengasamy, M.; Andino, B.; Chen, C.-H.; et al. Deposition of 5-methylcytosine on enhancer RNAs enables the coactivator function of PGC-1 $\alpha$. Cell Rep. 2016, 14, 479-492. [CrossRef]

108. Li, Q.; Li, X.; Tang, H.; Jiang, B.; Dou, Y.; Gorospe, M.; Wang, W. NSUN2-mediated M5C methylation and METTL3/ METTL14mediated m6A methylation cooperatively enhance P21 translation. J. Cell. Biochem. 2017, 118, 2587-2598. [CrossRef]

109. Van Tran, N.; Ernst, F.G.M.; Hawley, B.R.; Zorbas, C.; Ulryck, N.; Hackert, P.; Bohnsack, K.E.; Bohnsack, M.T.; Jaffrey, S.R.; Graille, M.; et al. The human 18S rRNA m6A methyltransferase METTL5 is stabilized by TRMT112. Nucleic Acids Res. 2019, 47, 7719-7733. [CrossRef]

110. Ma, H.; Wang, X.; Cai, J.; Dai, Q.; Natchiar, S.K.; Lv, R.; Chen, K.; Lu, Z.; Chen, H.; Shi, Y.G.; et al. $N^{6}-$ methyladenosine methyltransferase ZCCHC4 mediates ribosomal RNA methylation. Nat. Chem. Biol. 2018, 15, 88-94. [CrossRef]

111. Bertero, A.; Brown, S.; Madrigal, P.; Osnato, A.; Ortmann, D.; Yiangou, L.; Kadiwala, J.; Hubner, N.C.; de los Mozos, I.R.; Sadée, C.; et al. The SMAD2/3 interactome reveals that TGF $\beta$ controls m6A MRNA methylation in pluripotency. Nature 2018, 555, 256-259. [CrossRef]

112. Xiao, Y.; Wang, Y.; Tang, Q.; Wei, L.; Zhang, X.; Jia, G. An elongation and ligation-based qPCR amplification method for the radiolabeling-free detection of locus-specific $N^{6}$-methyladenosine modifications. Angew. Chem. 2018, 57, 15995-16000. [CrossRef] [PubMed]

113. Li, X.; Zhou, B.; Chen, L.; Gou, L.-T.; Li, H.; Fu, X.-D. GRID-seq reveals the global RNA-chromatin interactome. Nat. Biotechnol. 2017, 35, 940-950. [CrossRef] [PubMed]

114. Alberti, S.; Hyman, A.A. Biomolecular condensates at the nexus of cellular stress, protein aggregation disease and ageing. Nat. Rev. Mol. Cell Biol. 2021, 22, 196-213. [CrossRef] [PubMed]

115. Sabari, B.R.; Dall'Agnese, A.; Young, R.A. Biomolecular condensates in the nucleus. Trends Biochem. Sci. 2020, 45, 961-977. [CrossRef] [PubMed]

116. Su, X.; Ditlev, J.A.; Hui, E.; Xing, W.; Banjade, S.; Okrut, J.; King, D.S.; Taunton, J.; Rosen, M.K.; Vale, R.D. Phase separation of signaling molecules promotes T cell receptor signal transduction. Science 2016, 352, 595-599. [CrossRef] [PubMed]

117. Ahn, J.H.; Davis, E.S.; Daugird, T.A.; Zhao, S.; Quiroga, I.Y.; Uryu, H.; Li, J.; Storey, A.J.; Tsai, Y.-H.; Keeley, D.P.; et al. Phase separation drives aberrant chromatin looping and cancer development. Nature 2021, 595, 591-595. [CrossRef] [PubMed]

118. Roden, C.; Gladfelter, A.S. RNA contributions to the form and function of biomolecular condensates. Nat. Rev. Mol. Cell Biol. 2021, 22, 183-195. [CrossRef]

119. Ries, R.J.; Zaccara, S.; Klein, P.; Olarerin-George, A.; Namkoong, S.; Pickering, B.F.; Patil, D.P.; Kwak, H.; Lee, J.H.; Jaffrey, S.R. M6A enhances the phase separation potential of mRNA. Nature 2019, 571, 424-428. [CrossRef]

120. Fu, Y.; Zhuang, X. M6A-binding YTHDF proteins promote stress granule formation. Nat. Chem. Biol. 2020, 16, 955-963. [CrossRef]

121. Gao, Y.; Pei, G.; Li, D.; Li, R.; Shao, Y.; Zhang, Q.C.; Li, P. Multivalent m6A motifs promote phase separation of YTHDF proteins. Cell Res. 2019, 29, 767-769. [CrossRef]

122. Cheng, Y.; Xie, W.; Pickering, B.F.; Chu, K.L.; Savino, A.M.; Yang, X.; Luo, H.; Nguyen, D.T.; Mo, S.; Barin, E.; et al. N $N_{-}$ methyladenosine on MRNA facilitates a phase-separated nuclear body that suppresses myeloid leukemic differentiation. Cancer Cell 2021, 39, 958-972.e8. [CrossRef] [PubMed] 